\title{
Criminal Responsibility for the Spreading Personal Data on Twitter
}

\author{
Aris Hardinanto* \\ Faculty of Law \\ Universitas Trunojoyo \\ Madura, Indonesia \\ aris@trunojoyo.ac.id
}

\author{
Wati Anggraeni \\ Faculty of Law \\ Universitas Trunojoyo \\ Madura, Indonesia \\ anggraeni5498@gmail.com
}

\begin{abstract}
Internet and social media advancement leads to unrestricted communication exchange, including the personal detail information exposure. Cyber crimes are thus potential and one of the riskiest consequeneces is doxing; the personal data distribution without rights. Doxing is categorized as a cybercrime because it results in public insults, fake registration for services, hostage of interest, treath, and other harmful acts. This is normative research by using legal and theoritical approaches. The research aims to decide the qualification of acts of personal information distribution without rights on social media and to analyze the regulation about personal detail protection in relation to criminal liability in sharing the given data without rights on social media. The legal instruments used in this research are regulation, books, journals, published articles in media or individual relating to personal data, and KBBI (Kamus Besar Bahasa Indonesia). We also used grammatical law and futuristic interpretations as a legal material analysis. The research shows that the act of the personal data distribution on social media is a crime and the doer can be criminalized. There are few regulation ruling the personal data protection and its misusage in Indonesia. However, Law No 24 Year 2013 about Law Amendment No 23 Year 2006 about population administration underlies the law enforcement to this act.
\end{abstract}

Keywords: spreading, personal data, doxing

\section{INTRODUCTION}

Media Social media are online media. The users can participate, share, and create blogs, social networking, wiki, forum, and virtual world easily. Blog, social networking, and wiki are mostly popular across the globe. Some assert that social media are online media supporting more interactive exchanges especially when using web with technological basis.[1] Others also believe that social media facilitate easier and closer interpersonal relationship since the individuals tend to be more demonstrative, let others know themselves.

Their existences can be shown by their regular status updates, comments, and notes. Implementing the criminal law is to prevent the increasingly cybercrime phenomena.[2] A part of them is categorized as a "new wine, new bottle", the crime committed after the internet presents. Indonesian cyber regime regulates the proof system. The misuse of social media can be exemplified by hate speech, hoax, public opinion framing and they are all illegal. Because of that reason, cyber law made.[3] In Indonesian context, the idea relates to cybercrimes.[4] One of the debatable issues in this current research is the phenomenon on Twitter.

It starts from the viral video displaying a man intended to slaughter Jokowi (the President of Indonesia).[5] The video was taken from a group of people entitled Gabungan Elemen Rakyat untuk Keadilan dan Kebenaran (GERAK henceforth/people association for justice and truth) when protesting the government in front of the Election Supervisory Agency of the Republic of Indonesia at 9th of May, 2019. Various comments followed and at May 11, 2019 , other comment included the photographs, full name, place of birth, Card identity no (NIK henceforth), status, and residential addresses of the alleged doers: Cep Yanto and Dheva Suprayoga.[6] They were twitted by an account on Twitter. Those personal details at least were accessed from the Civil Service and Registration (Dispendukcapil henceforth). The information deploys. Then the user of the Twitter account removed the contents but they remain captured. The act is considered to be doxing because the the user has no rights to share personal information of others.

Based on the given phenomena, this formulates two research problems:

1. Is distributing other personal information without rights a crime?

2. How the criminal liability of that act can be committed?

\section{RESEARCH METHOD}

This is a legal normative research by using legal approaches. It means that the research is based on the existing law either in the form of book of criminal law (KUHP henceforth) Indonesia, the law, or scientific works such as books or articles which are relevant to this research available on the internet.[7] This is to look at how the law regulates, responds, and addresses the following consequences along with the act of personal information distribution without rights on social media. The statue approach was used to analyze the law and regulation pertaining to the legal issue under discussion. 


\section{RESULTS AND DISCUSSION}

\section{A. Criminal Acts, Criminal Liabiluty, and Civil Data Protection}

The definition of the criminal act in KUHP is more popular with strafbaarfeit in books. Whereas, the law makers used the term "criminal event" or "criminal acts". Experts commonly used strafbaarfeit that is translated into criminal event that covers the criminal acts, derived from three words: straf means crime and law, baar means could, and feit means act, event, violation, act so that strafbaarfeit means acts that can be sentenced. Other language used delict to indicate the act that is subject for crime. E.Y. Kanter dan S.R. Sianturi assert that there are five elements in criminal acts: subject, false, their nature against the law, categorized as a ban or obligation by the Law and the doers are sentenced, tempus (time), locus (place), and condition. The crimes occur because criminal acts present based on the false done by someone. That false results in insults relating to absence and intention. The form of the false is absence (culpa) and intention (dolus).[8]

Meanwhile, the false (schuld) can lead to criminal acts when the acts are against the law and must be responsible and as a consequence, they can be categorized as criminal acts of what are being effort. Eventhough they are right, they still remain subject for crimes. The acts are considered to be criminal when they are banned legally, encompass acts opposing law, in nature against the law, and the absence of justification to support the acts. Someone cannot be held responsible when they are not liable.[9] There is no precise definition of the ability to be liable, but it can be associated with Article 44 Verse (1) KUHP stating "anyone who commit irresponsible acts and they do not hold liability due to their physical or soul defects due illness are not subject for crime". Based on that article, Moeljatno overviewed on ability to responsible by stating that there is a need to be able to differ between good deed and bad deed, legal or against the law, rather than deciding the issue based on individual's perception.[10]

The purpose of criminal liability is to decide either the suspect/defendant must (not) bear responsibility to the committed crime. False consists of two deeds: intentional and unintentional. When things done intentionally, it means that the doer has an ability to see the legal prohibition and order and the consequences may be caused. In other words, the act suits what was pictured before.[11] Moeljatno believes in theoretical knowledge in which the intention is embedded in the nature of the knowledge. Knowing what they want is the case of wishing something. Acts are considered to be unintentional when the doer does not mean to violate the legal order.

Unintentional acts mean that the individuals do not violate the regulation on purpose. In other words, they do not heed the prohibited actions ruled by the regulation leading to ignorance may be caused. This could be the reason to criminal abolition. The criminal abolition consists of two types: the first is the general criminal. This is applied to the public exemplified by Article 44, 48, to 51 KUHP; the second is the special crime, applied to a specific crime. Their criminal abolition is associated with actions or doers so that they are categorized into two parts; justification and excuse. Even though the actions have met the criminal criteria, justification can close the nature of opposing law down. The excuse perceived the doers of the crimes cannot be sentenced as they cannot be blamed and or bear responsibility. Therefore, they are not sentenced because their acts are excused. There are two types of excuse: overmatch stated in Article 48 KUHP, noodweer stated in Article 49 verse (2) KUHP and invalid department order, but the doers perceived the acts are legal as stated in Article 52 verse (2) KUHP.

The definition of the Electronic Information from Law No 19 Year 2016 about the amendment of Law No 11 Year 2008 about Information and Electronic Transaction (UU ITE henceforth), refers to a collection of electronic data, including but not limited to written text, voice, picture, map, photo design, electronic data interchange, electronic mail, telegram, telext, telecopy, or alike, letter, symbol, number, code access, symbols, or perforation that has been modified to be meaningful or can be understood by certain people. Personal data, stated in Article 1 no 22 Law No 24 Year 2013 about the Amendment of Law No 23 Year 2006 about Population Administration, are personal data in which the truth is stored and maintained and their confidentiality is kept.

A more detailed definition is explained in Article 1 No 2 Regulation of the Minister of Communication and Information and the Republic of Indonesia No 20 Year 2016 about the personal data protection in Electronic System stating that "the personal data are true and real embedded and identifiable, directly or indirectly, on the data holders in which the use is based on the regulation." Personal data are personal privacy. It is irrelevant to be obtained easily without permission of the holder. In Indonesian context in accordance with the increasingly use of internet and social media, there has been no rules and regulation ruling the personal data protection. Consequently, the personal data can be misused for personal, business, and political interests.[12]

Theft, burglary data and shared-information without rights are examples and are used to commit other crimes. The rampant abuse of personal data underlies the urgency of specific law making protecting personal data in Indonesia. [13]Therefore, the crime as mandated in Article 40, based on Article 56 UU ITE is sentenced for 15 years at the longest.

\section{B. The Criminal Liability of Personal Data Distribution On Twitter}

Sharing personal data without right based on Law No 24 Year 2013 about the amendment of Law No 23 Year 2006 about Population Administration is prohibited. It is mandated in Article 79 verse (3) "the officials and users as stated in Verse (2) are banned to share the population data irrelevant to their authority". One of the elements embedded 
in this article is subjective element in which the subject in this perspective refers to the officials and users. Based on the Article 79 Verse (2), the officials are in the province level and implementing agency officers. In the province level, the officials are responsible and have authority to carry out services in population administration affairs. Implementing agency officers are governments staffs in district/city level who are responsible and have authority to provide population administration affair services. Furthermore, there has been the element of action objectives that are banned or against for, the word "banned" could be the key. The ban refers to a phrase "sharing population data" and is strengthened by the phrase "irrelevant to their authority". In regards with the personal data distribution, it is clear that the subject shared the personal data of others by posting them (in official form of population data) in his social media. The captures of Cep Yanto and Dheva Suprayoga's personal information are rampant and undeletable so far.

Violation against for Article 79 Verse (3) and Article 86 Verse (1) Law of Population Administration based on Article 95A will be imprisoned for 2 (two) years at length and or fined 25,000,000,000,00 at maximum. The personal information that are presented, announced, received, and distributed by the officials must be the subject of agreement by the holders as mandated in Article 26. The capability to bear responsibility of the doers is counted from the time the doer commits the crimes, so that he must be normal psychologically. Simons argues that the doer can be said to be able to responsible to their action if his psychological states are healthy, is able to show legal responsibility, and is able to decide his wish according to his consciousness.

The ability to bear responsibility is defined as a consciousness that justifies the existing peaceful efforts either seen from public or personal point of view. Based on the chronology of the event, the owner of Twitter account intentionally shared the personal data of two people accused on the video. Even though he finally removed his postage, he can be asked his criminal liability because of his intention in distributing the personal data in social media. It indicates that he is actually conscious and understands the possible consequence of his act. The act meets the element requirement of population data distribution without right on social media stated in Article 79 Verse (3) jo Article 95A Law of Population Administration in relation to the distribution of personal data information

\section{CONCLUSIONS AND SUGGESTIONS}

From the explanation above, we can conclude that:

1. The act of distributing the population data information on social media can be categorized as a criminal act because it violates Article 79 Verse (3) jo Article 95A about Population Administration in relation to the distribution of personal data information;
2. 2. The doer has the capability to bear responsibility because he is conscious and understands the potential risks of what he is doing. It falls into crimes because the act is intentionally and consciously done, while sharing them on his social media account is without rights and therefore he can be meshed by Article 79 Verse (3) jo Article 95A about Law of population Administration in relation to the distribution of personal data information.

Suggestion to this issue are:

1. The law making in specifically protecting personal data is required;

2. There is a need of evaluation toward access mechanism of population data confidentiality and it must be based on Law of personal data protection.

\section{ACKNOWLEDGMENT}

This research is funded by Law Faculty, Universitas Trunojoyo Madura.

\section{REFERENCES}

[1] D. Mulawarman and A. D. Nurfitri, "Social Media User Behavior and Implications Based on SocialApplied Psychology Perspective," vol. 118, pp. 378-382, 2017.

[2] M. Herlina and R. P. Jati, "The Influence of Cybercrime Against Teenage Angst in Online Media," vol. 343, no. Icas, pp. 379-382, 2019.

[3] E. Mulyadi and H. Gusfa, "The Regulation (ITE Law) Socialization and Implementation Model by Kominfo to Mitigate Negative Content on Social Media," vol. 343, no. Icas, pp. 474-479, 2019.

[4] M. S. Neyasyah, "Legal Resilience in the Phenomenon of Social Media Political Buzzer in Indonesia," vol. 130, no. Iclave 2019, pp. 338-344, 2020.

[5] "Man threatening to behead Jokowi in viral video reported to police," 2019. [Online]. Available: https://www.thejakartapost.com/news/2019/05/12/m an-threatening-to-behead-jokowi-in-viral-videoreported-to-police.html.

[6] R. P. Danu Damarjati, "Kritik untuk Ulin Yusron yang Asal Tuduh-Sebar Data Pribadi Milik Orang," Detik, 2019. [Online]. Available: https://news.detik.com/berita/d-4547079/kritikuntuk-ulin-yusron-yang-asal-tuduh-sebar-datapribadi-milik-orang.

[7] P. M. Marzuki, Penelitian Hukum. Jakarta: Kencana Prenada Media, 2010.

[8] A. Ilyas, Asas-Asas Hukum Pidana: Memahami Tindak Pidana dan Pertanggungjawaban Pidana Sebagai Syarat Pemidanaan. Yogyakarta: Mahakarya Rangkang Offset, 2012.

[9] Y. Kurniaty and S. S. Pinilih, "Various Level of 
Aggressive Behavior of Schizophrenia as a Basis of Criminal Responsibility," vol. 436, pp. 128-131, 2020.

[10] Moeljatno, Asas-asas Hukum Pidana. Jakarta: Bina Aksara, 1984.

[11] Habiburokhman, F. Supanto, and S. Ummul, "The Aspect of Criminal Liability in Law Enforcement for the Prohibition on Hate Speech on Social Media," vol. 358, no. Icglow, pp. 202-205, 2019.

[12] F. W. Sari, "Law Protection forward Privacy Data of Social Media User According to International and National Law," vol. 225, no. Icobest, pp. 341-345, 2019.

[13] R. Butarbutar, "Initiating New Regulations on Personal Data Protection: Challenges for Personal Data Protection in Indonesia," vol. 130, no. Iclave 2019, pp. 154-163, 2020. 